\title{
Coprecipitation of Copper(II)-Humic Complexes with Indium Hydroxide
}

\author{
Masataka Hiraide, Hiroshi Hommi and Hiroshi KawaguchI \\ Faculty of Engineering, Nagoya University, Nagoya 464-01, Japan
}

Keywords Water analysis, coprecipitation, indium hydroxide, copper(II)-humic complexes, humic acid, fulvic acid

Concentration of traces of heavy metals is often required prior to the instrumental determination to lower the detection limits and to improve the precision and accuracy of analytical results. Coprecipitation with indium hydroxide is one of the most effective multielement preconcentration techniques in water analysis. 1,2 It is directly combined with inductively-coupled plasma (ICP) atomic emission spectrometry because of the simple emission spectrum of indium ${ }^{1}$ and also combined with graphite-furnace atomic absorption spectrometry because of ease of removal of indium as bromide at the ashing stage. ${ }^{3}$

Traces of heavy metals in natural waters, however, exist in various physicochemical forms ${ }^{4}$, which may exhibit different separation behavior in coprecipitation. According to the previous work ${ }^{2}$, hydrated heavy metal ions, hydroxo complexes, inorganic colloids and suspended particles are simultaneously coprecipitated with indium hydroxide at $\mathrm{pH} 9.0$ to 9.5 . The behavior of metal-humic complexes, however, is not quite clear because neither coprecipitation of fulvic acid complexes nor interference of soluble silica (monosilicic acid) has been discussed at all.

Humic and fulvic acids are the major organic constituents in natural waters and interact with metal ions to form water-soluble complexes. ${ }^{5}$ Actually, $60-$ $70 \%$ of the copper dissolved in river water was found to be humic complexes. ${ }^{6,7}$ In the present work, therefore, coprecipitation of copper(II)-humic complexes as well as humic and fulvic acids was studied in detail in the presence of soluble silica. Analytical results for copper in river water obtained by coprecipitation closely agreed with those obtained by evaporation, indicating that nearly all copper species can be collected on indium hydroxide.

\section{Experimental}

\section{Apparatus}

A Shimadzu UV-180 spectrophotometer with $5-\mathrm{cm}$ cells was used for the measurement of absorbance of humic and fulvic acids. A Seiko I \& E SPQ-6100A
ICP-mass spectrometer was used for the determination of heavy metals.

\section{Reagents}

A humic acid solution $\left(0.50 \mathrm{mg} \mathrm{ml}^{-1}\right)$ was prepared by dissolving humic acid (Nakarai Chemicals) in $0.1 \mathrm{M}$ potassium hydroxide and filtering through $0.4-\mu \mathrm{m}$ Nuclepore filters; the absorptivity of the solution was $12 \mathrm{mg}^{-1} \mathrm{~cm}^{2}$. Fulvic acid ${ }^{8}$ was dissolved in water $\left(1 \mathrm{mg} \mathrm{m}^{-1}\right)$; the absorptivity was $0.86 \mathrm{mg}^{-1} \mathrm{~cm}^{2}$.

An indium solution $\left(10 \mathrm{mgIn} \mathrm{ml}^{-1}\right.$, in $0.1 \mathrm{M}$ nitric acid) was prepared from $99.9999 \%$ indium metal (Rear Metallic). A silica solution $\left(1 \mathrm{mgSi} \mathrm{ml}^{-1}\right)$ was prepared by dissolving sodium silicate in water.

A macroreticular anion-exchanger, diethylaminoethyl Sephadex A-25 (Pharmacia Fine Chemicals), was ultrasonically washed in $0.1 \mathrm{M}$ hydrochloric acid, followed by washing in water. The supernatant solution was neutralized with $1 \mathrm{M}$ sodium hydroxide; then the slurry was transferred into a column $(5 \mathrm{~mm}$ diam. $\times 30 \mathrm{~mm}$ ).

\section{Procedure}

To a $50-\mathrm{ml}$ sample was added $0.5 \mathrm{ml}$ of indium solution and the $\mathrm{pH}$ was adjusted to different values with 0.01 and $0.1 \mathrm{M}$ potassium hydroxide. The solution containing indium hydroxide was stirred for $5 \mathrm{~min}$; then the precipitate was centrifuged at $3000 \mathrm{rpm}$ for $10 \mathrm{~min}$. The supernatant solution was collected and reserved for the determination of humic substances by spectrophotometry at $400 \mathrm{~nm}$ or determination of heavy metals by ICP-mass spectrometry (ICP-MS). The precipitate in the centrifuge tube was dissolved in $1 \mathrm{ml}$ of $1 \mathrm{M}$ nitric acid; then the solution was diluted to $2 \mathrm{ml}$ with water for ICP-MS.

\section{Results and Discussion}

Indium hydroxide was precipitated at different $\mathrm{pH}$ values from water containing humic or fulvic acid. The humic recovery was obtained spectrophotometrically as described in Procedure. Similar experiments were 
carried out with iron(III) hydroxide. Figure 1 illustrates the effect of $\mathrm{pH}$ on coprecipitation. Both hydroxides were formed at $\mathrm{pH} \mathrm{6}$, where humic substances were collected quantitatively. Humic and fulvic acids were recovered in greater than $90 \%$ yields at the pH up to 9.5 or 8.0 with indium or iron(III) hydroxide, respectively. The recovery, however, rapidly decreased at higher pH's.

River water generally contains appreciable amounts of soluble silica, which interfere with coprecipitation of humic substances, especially in alkaline solutions, as shown in Fig. 2. For example, in the case of indium hydroxide, humic or fulvic acid decreased in recovery from $95 \%$ to $70 \%$ at $\mathrm{pH} 9.5$

Coprecipitation with indium hydroxide is recommended at the $\mathrm{pH}$ range of 9.0 to 9.5 , where various heavy metal ions are simultaneously and quantitatively

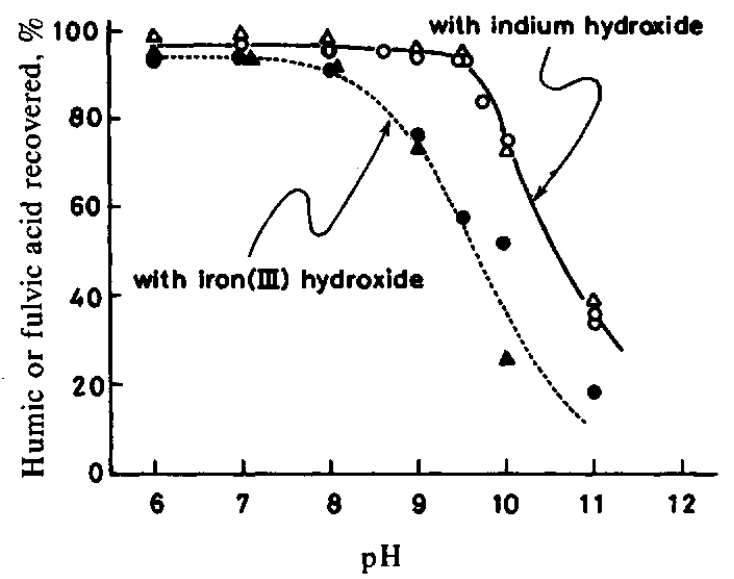

Fig. I Coprecipitation of humic substances with indium or iron(III) hydroxide. Sample volume $50 \mathrm{ml}$; humic acid $5 \mu \mathrm{g}$ $\mathrm{ml}^{-1}(\mathrm{O}, 0)$; fulvic acid $50 \mu \mathrm{g} \mathrm{ml}^{-1}(\Delta, \Delta)$; indium or iron(III) $100 \mu \mathrm{g} \mathrm{ml}^{-1}$.

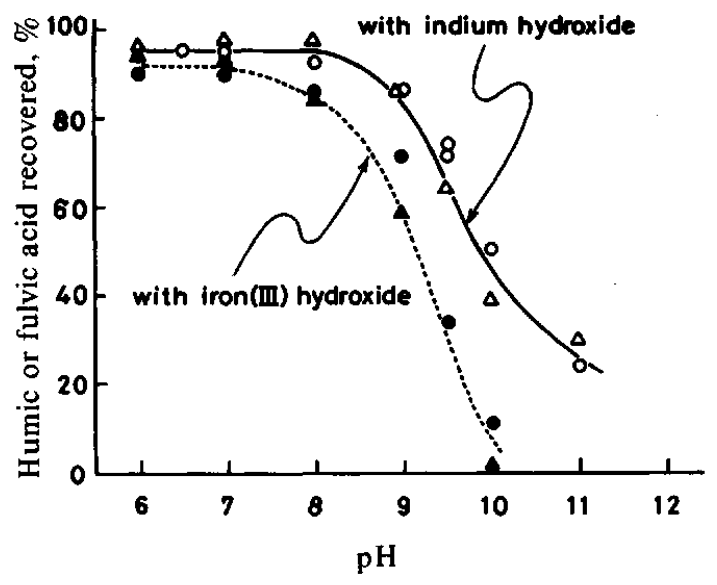

Fig. 2 Coprecipitation of humic substances in the presence of soluble silica. Sample volume $50 \mathrm{ml}$; humic acid $5 \mu \mathrm{g} \mathrm{ml}^{-1}$ $(\mathrm{O}, O)$; fulvic acid $50 \mu \mathrm{g} \mathrm{ml}^{-1}(\Delta, \Delta)$; silica $10 \mu \mathrm{gSi} \mathrm{m}^{-1}$; indium or iron(IIl) $100 \mu \mathrm{g} \mathrm{ml}^{-1}$. coprecipitated, leaving alkali and alkaline earth metals in the solution. ${ }^{1}$ Therefore, copper(II)-humic complexes were prepared to examine whether metal-humic complexes behave similarly to humic or fulvic acid. A copper(II) solution ( $\mathrm{pH} \mathrm{3-4)}$ was mixed with a humic or fulvic acid solution ( $\mathrm{pH} 7$ ) and the $\mathrm{pH}$ was adjusted to 7.0 with $0.1 \mathrm{M}$ potassium hydroxide. About a half of the copper $(45-55 \%)$ was complexed with humic substances, which was obtained by analyzing the effluent by ICP-MS after the sorption of negatively charged humic complexes on a Sephadex A-25 column. ${ }^{9,10}$ As shown in Table 1, nearly complete recoveries were obtained for copper at $\mathrm{pH} \mathrm{9.5,} \mathrm{in} \mathrm{the}$ absence or the presence of soluble silica. Coprecipitation was also quantitatively achieved even at $\mathrm{pH} 10.5$, where the recovery of humic or fulvic acid was only $30 \%$ in the presence of silica. At present, it is unclear whether the copper is coprecipitated as humic complexes or as inorganic species of copper released from the complexes.

The above findings and our previous work ${ }^{2}$ prove that coprecipitation with indium hydroxide can give the total copper present in water. The coprecipitation method was compared with the evaporation method for

Table 1 Coprecipitation of copper(II)-humic complexes with indium hydroxide

\begin{tabular}{lccc}
\hline \multicolumn{2}{c}{$\begin{array}{c}\text { Sample } \\
\text { containing } / \mu \mathrm{g})\end{array}$} & \multicolumn{2}{c}{ Cu coprecipitated, \% } \\
\cline { 3 - 4 } & $\mathrm{pH} \mathrm{9.5}$ & $\mathrm{pH} 10.5$ \\
\hline $\mathrm{Cu}$ & 2.5 & 98 & 97 \\
Humic acid & 250 & & \\
$\mathrm{Cu}$ & 2.5 & 99 & 99 \\
Fulvic acid & 250 & & \\
$\mathrm{Cu}$ & 2.5 & 99 & 98 \\
Silica & 500 (as Si) & & \\
Humic acid & 250 & & \\
Cu & 2.5 & 99 & 99 \\
Silica & 500 (as Si) & & \\
Fulvic acid & 250 & & \\
\hline
\end{tabular}

a. $45-55 \%$ of $\mathrm{Cu}$ was complexed with humic or fulvic acid.

Table 2 Determination of copper in river water

\begin{tabular}{|c|c|}
\hline \multicolumn{2}{|c|}{$\mathrm{Cu} / \mu \mathrm{gl}^{-1}$} \\
\hline Coprecipitation $^{b}$ & Evaporation \\
\hline \multicolumn{2}{|c|}{ Kiso River ${ }^{\mathrm{a}}$} \\
\hline $\begin{array}{l}0.4,0.4,0.6 \\
\quad \text { (av. 0.5) }\end{array}$ & $\begin{array}{c}0.4,0.5,0.6 \\
\quad \text { (av. } 0.5 \text { ) }\end{array}$ \\
\hline \multicolumn{2}{|c|}{ Shonai River ${ }^{\mathbf{a}}$} \\
\hline $\begin{array}{l}1.1,1.2 \\
\text { (av. 1.2) }\end{array}$ & $\begin{array}{l}1.2,1.2 \\
\text { (av. 1.2) }\end{array}$ \\
\hline
\end{tabular}

a. Passed through a $1-\mu \mathrm{m}$ Nuclepore filter.

b. At $\mathrm{pH} 9.5$. 
the determination of copper in filtered river water samples. In the latter, $20 \mathrm{ml}$ of sample was gently evaporated to dryness and the residue was dissolved in $2 \mathrm{ml}$ of $0.5 \mathrm{M}$ nitric acid. The results obtained by the two methods are in good agreement with each other, as shown in Table 2. Compared with evaporation, coprecipitation allows higher concentration factors to be attained with less time consumed.

Coprecipitation with indium hydroxide can also be applied to determine total concentrations of other heavy metals, because $\mathrm{Co}(\mathrm{II}), \mathrm{Ni}(\mathrm{II}), \mathrm{Zn}(\mathrm{II}), \mathrm{Cd}(\mathrm{II})$ and $\mathrm{Pb}(\mathrm{II}), 50 \mu \mathrm{gl}^{-1}$ each, were coprecipitated in greater than $92 \%$ yields from water containing humic acid (5 $\mathrm{mg} \mathrm{l}^{-1}$ ).

\section{References}

1. M. Hiraide, Г. Ito, M. Baba, H. Kawaguchi and A.
Mizuike, Anal. Chem., 52, 804 (1980).

2. M. Hiraide, J. Mizutani and A. Mizuike, Nippon Kagaku Kaishi, 1981, 161

3. M. Hiraide, Z.-S. Chen and H. Kawaguchi, Anal. Sci., 7, 65 (1991).

4. T. M. Florence, Talanta, 29, 345 (1982).

5. S. Boggs, D. G. Livermore and M. G. Seitz, J. Macromol. Sci. -Rev. Macromol. Chem. Phys., C25, 599 (1985).

6. M. Hiraide, Y. Arima and A. Mizuike, Anal. Chim. Acta, 200, 171 (1987).

7. M. Hiraide, M. Ishii and A. Mizuike, Anal. Sci., 4, 605 (1988).

8. S. Arai and K. Kumada, Soil Sci. Plant Nutr., 29, 543 (1983).

9. M. Hiraide, S. P. Tillekeratne, K. Otsuka and A. Mizuike, Anal. Chim. Acta, 172, 215 (1985).

10. M. Taga, S. Tanaka and M. Fukushima, Anal. Sci., 5, 597 (1989).

(Received November 7, 1990)

(Accepted December 5, 1990) 